\title{
REMOTE
}

\section{For Brush Encroachment}
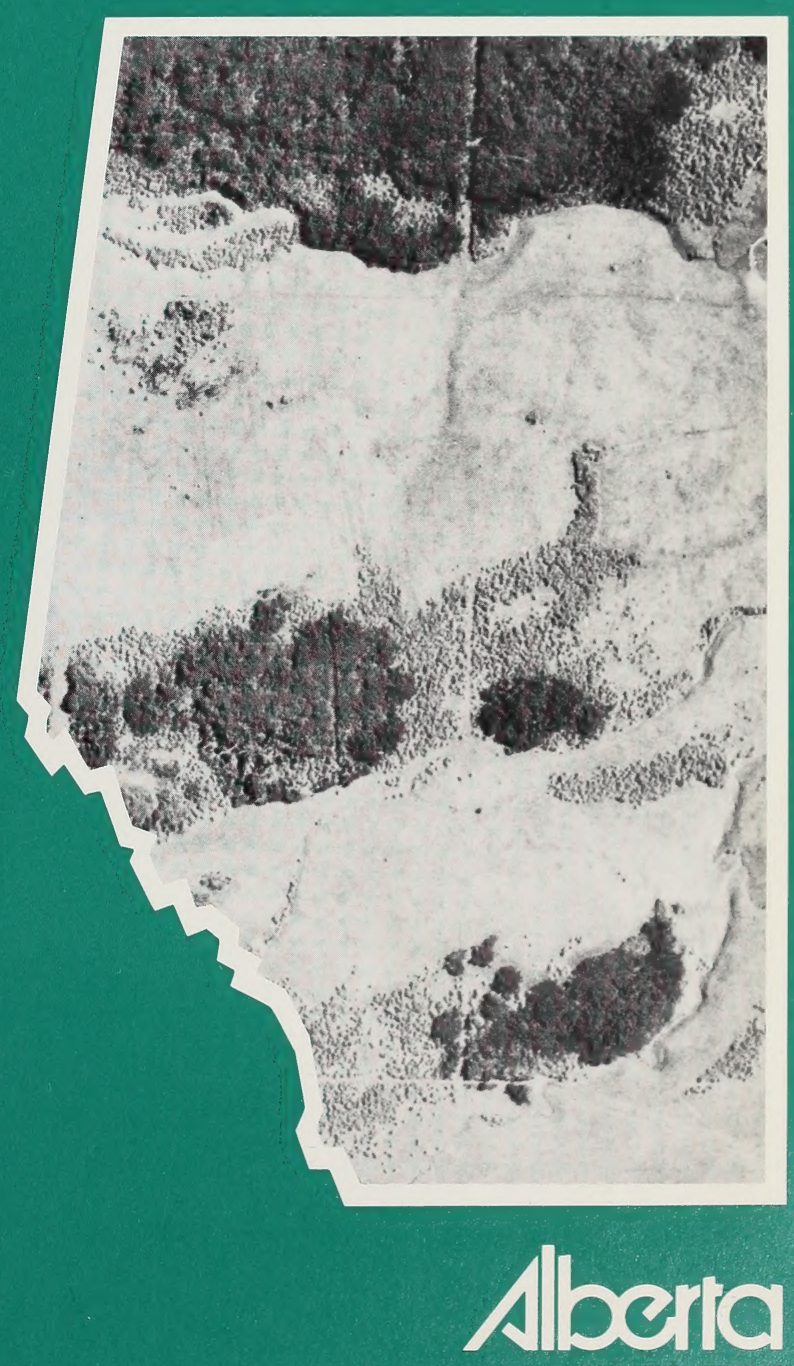

ENVIRONMENT 

REMOTE SENSING FOR BRUSH ENCROACHMENT

Landsat Monitoring of Brush Encroachment

in Fescue Grasslands of Southwest Alberta

by

M. DIANE THOMPSON

INTERA TECHNOLOGIES LTD.

Calgary, Alberta

( PUBLICATION NO. 84-1

ALBERTA REMOTE SENSING CENTER

11th Floor, 9820 - 106 Street

Edmonton, Alberta

T5K 2J6 
Digitized by the Internet Archive in 2015

https://archive.org/details/remotesensingfor00thom 
Ms. Thompson, Vice president in charge of Biophysical Services, INTERA Technologies Ltd., Calgary, is responsible for the management and operations of the above technical group, in addition to carrying out research and applications studies related to remote sensing and the environment.

Ms. Thompson has a Master of Science degree from the University of Western Ontario in Geography/Remote Sensing, and has been working in the environmental consulting field since 1972. She has been a member of the Canadian Advisory Committee on Remote Sensing Working Group on Geography since 1976 (presently Chairman), and of the Agriculture Working Group (1982-83).

\section{ACKNOWLEDGEMENTS}

The contribution of Dr. Alex Johnston (retired), Agriculture Canada, Lethbridge Research Station, and S.G. (Bud) Klumph, Lands Division, Alberta Energy \& Natural Resources, Lethbridge, of historic and current information on the brush encroachment problem and on the study area in particular is gratefully acknowledged. Dr. Johnston also made the 1977 Stavely aerial photographs available for the study. S.J. Nelson (then with INTERA) carried out the field work and part of the air photo interpretation. Contributions from local rancher and numerous government agencies were also appreciated. Alberta Transportation in Edmonton made the Dominion surveyor notebooks available for photocopying. Finally, the Canada Centre for Remote sensing (CCRS) (Dr. K.P.B. Thomson, Scientific Liaison) made available their image analysis system (CIAS) for the Landsat analysis.

\section{DEMONSTRATION PROJECT}

This is the abridged edition of a remote sensing demonstration project report sponsored by the Alberta Remote sensing Center, Alberta Environment. The complete report is available for in-Center study.

\section{COVER PHOTOGRAPH}

Brush encroachment on the Stavely Research Substation (Agriculture Canada) in southwestern Alberta (panchromatic aerial photograph YC 537-28, 23 June 1962). 

The encroachment of woody brush onto the native rangelands in western Canada leads to a decrease in their quality and productivity. This study evaluates the use of remote sensing as a tool for inventory and monitoring of brush encroachment in a southwestern Alberta study area. Brush location data for three transects, each about $20 \mathrm{~km}$ long, were obtained over an 80-year period, from Dominion of Canada surveyor records around 1900, from 1952 and 1962 panchromatic and 1977 colour infrared aerial photographs, from 1973 and 1980 Landsat data, and from ground surveys in 1980. The location of brush from each data set was mapped onto a common map base $(1: 50,000$ scale), and the changes over the four major time intervals compared. The measurements showed average values of encroachment of brush in all three transects in agreement with results cited in the literature. The study showed that a wide variety of types of remote sensing data can provide consistently accurate evaluations of both brush encroachment and brush clearance. Landsat data are particularly useful for relatively inexpensive monitoring over large areas; this can be done on an annual basis for brush clearance monitoring, and over longer time intervals for evaluation of natural brush encroachment. 
1. Location of the Brush Encroachment Study Area in

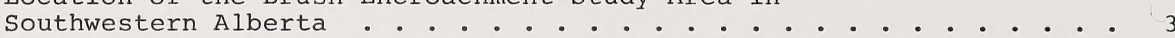

2. Examples of Historic and Current Data . . . . . . . . . . . . . 5

3. CIR Photograph (A37530 IR-101, 1:7,500 scale). Obtained 13 September 1977, of North Boundary of Stavely Research Substation (22-14-29-W4), with Overlay (back pocket of this publication) Illustrating Brush Encroachment Since 1907 . . . . . . 8

4. View of Encroaching Willow in Abandoned Field, Noted on 1977 CIR Photograph (looking east, 14 July 1977, Stavely Research Substation)

5. Brush and Open Areas Mapped from 1962 Photographs (top) and from 1980 Landsat Data (centre) for Six Sections in Transect 2. Bottom Map shows Brush Encroachment and Clearance which Took Place During the 1962-1980 Interval . . . . 10

6. Colour Prints of 1973 (top) and 1980 (centre)

Contrast-Stretched Landsat Digital Data, with Transect 2 Outlined on Each. Bottom Photograph shows a Multitemporal

Overlay of Band 5 Data from 1974 and 1980 . . . . . . . . . . . . 11

7. Brush Cover Percentage Changes in Three Transects During Four Intervals from 1900 - 1980, as Measured from Surveyor and Remote Sensing Data... . . . . . . . . . . . . . . 13

LIST OF TABLES

1. Remote Sensing and Ground Data Used for Brush Encroachment Study. . . . . . . . . . . . . . . . . . . . 4

2. Summary of Brush Cover Changes from 1900-1980 in Three Transects . . . . . . . . . . . . . . . . . . 13 
BACKGROUND . . . . . . . . . . . . . . . . . . . . . . . . . . 1

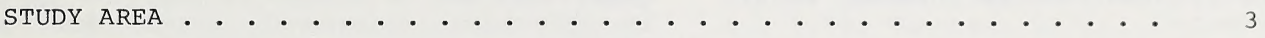

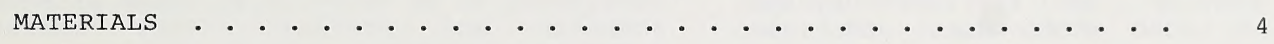

METHODS •. . . . • . . . . . . . . . . . . . . . . . . . . 6

Methods for Analysis of Aerial Photograph and Surveyor Data . • . . . . 6

Field Data Collection and Analysis . . . . . . . . . . . . . . . . 6

Methods of Landsat Analysis . . . . . . . . . . . . . . . . . 6

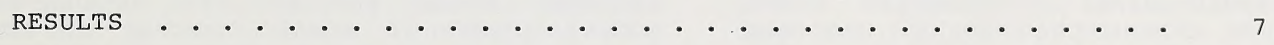

DISCUSSION • • • • • • • • • • • • • • • • • • • • • • •

CONCLUSIONS • • • • • • • • • • • • • • • • • • • • • • • • • • . 14

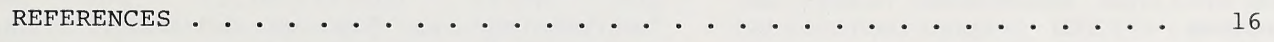


and Wroe 1974), over-utilization of land by

The rangelands of Western Canada constitute a valuable resource for livestock and wildlife, as well as for recreation, timber and fossil fuels. Remote sensing has proven to be a beneficial tool for rangeland management, assisting range managers by maximizing their efficiency, expanding their area of coverage, reducing intervals of range monitoring, and permitting economical inventories of remote areas. One important concern of today's range manager is the decreasing quality of the range, especially in view of increasing demand on this resource by other users. One reason for the decrease in quality and productivity of the rangelands is the encroachment of woody shrubs. The problem is well studied (Bailey and Wroe 1974; Bailey 1972; Johnston and Smoliak 1968; Coupland and Maini 1959), but the extent of the problem has been documented only for local areas and varies according to geographic location. The full extent of the problem remains unknown, or at least undocumented.

Through its wide area coverage, remote sensing may provide a tool for inventory and monitoring of brush encroachment onto the Western Canadian range. This study uses historic and current remote sensing and ground survey data to evaluate their usefulness in supplying range managers and others with accurate and timely information concerning the extent of the problem.

\section{BACKGROUND}

The Alberta Parkland extends as an ecotone between the boreal forest and/or subalpine forest and the grasslands in a broad belt across southcentral Alberta and southwestward along the Rocky Mountain foothils to the U.S. border. The generalized ecological succession sequence is grass to willow to aspen to conifer (Johnston and Smoliak 1968). Along the foothills, the zone is narrow, and at times discontinuous, since rapid increases in elevation and precipitation produce rapid changes in soil moisture conditions (North 1976).

The parkland area has fluctuated widely in location because of its responsiveness to natural and man-induced environmental change (North 1976), with brush frequently invading the fescue (Festuca scabrella) grassland (Bailey and Wroe 1974, Johnston and Smoliak 1968, Stelfox 1979). Typical brush species include prickly rose (Rosa acicularis), snowberry (Symphoricarpos alba), willow (Salix spp.), aspen (Populus tremuloides), and balsam poplar (Populus balsamifera). There was little brush on the rangelands of southwestern Alberta 85 years ago (Johnson and Smoliak 1968). During the early $1900^{\prime} \mathrm{s}$, however, settlement restricted prairie fires, grazing pressures were reduced by elimination of the bison, and cattle were not yet numerous. As a result, grass growth became heavier, and woody brush growth from moist valley bottoms, slopes and deep coulees invaded the grassland area (Stelfox 1979). Climatic changes (Bailey livestock, and farm abandonment (Friesen et al. 1965) allow shrubs to rapidly take over large areas (North 1976).

Rates of brush encroachment vary due to location, species and climate. Bailey and Wroe (1974) found annual invasion rates of $0.05 \%$ in their central Alberta study area, compared to an annual $0.75 \%$ in the wetter Porcupine Hills (Johnston and Smoliak 1968); drier areas appear to have lower rates of encroachment. Maini (1960), as quoted in Bailey and Wroe (1974), found invasion rates of 0.02 to $0.50 \%$ in his Saskatchewan study area. Stelfox (1979) measured the highest percentage annual increases in tree cover as 1.7\% in southern Saskatchewan. Bailey and Wroe (1974) also conclude that the rate of invasion may be increasing because of the greater number of brush patches being established.

Although brush encroachment onto the grasslands may be viewed as positive in that it provides increased cover for some wildlife species, and thus, an increased area of habitat, its impact is generally considered to be negative by range managers. Johnston and Smoliak (1968) measured reductions in forage yields of $66 \%$ from the fescue grasslands $(1350 \mathrm{~kg} / \mathrm{ha})$ to aspen groves $(450 \mathrm{~kg} / \mathrm{ha})$. Bailey and Wroe (1974) estimated an average $88 \%$ reduction in annual herbage production $(84 \%$ under willow and $92 \%$ under aspen). Such decreases in forage growth have a significant economic impact on ranching in the native range areas, where beef cattle production is important.

The rate of encroachment of brush onto the grasslands of southern Alberta is geometric: as more brush patches are established, annual growth in areal coverage of brush increases. New patches are established each year, old patches grow on all sides, and grassy areas between are filled in with brush.

Remote sensing has been used successfully to detect changes in land use, land cover, and environmental parameters. For the last three decades, increasing use has been made of aerial photography (particularly black and white panchromatic) for such "monitoring" or "change detection", using traditional interpretation and mapping techniques. In such studies, baseline conditions are mapped from photographs; these are then compared with information mapped from sequential photography of the same area (Brothers and Fish 1978).

Many researchers have reported the simple technique of measuring total area covered by the parameters of interest on each set of remote sensing data (or on the resultant maps). These figures are then compared to determine the change in total area (Avery 1965; Brothers and Fish 1978; Richter 1969; Roller 1978; Dalsted 1978; and others).

Numerous other techniques developed to replace the more traditional methods include overlaying of positive and negative transparencies (Reeves 1975; Simonett 1974), 
use of electronic scanning devices and density slicing (Ross 1976), and various forms of image enhancement (tone contrast stretching, Agfacontour density-slicing) (Nielsen 1972; Clarke 1967; Simonett 1974).

Since the launch of Landsat 1 in 1972, much research has been focussed on the application of satellite data to resource inventory and monitoring, and to assessment of land use/cover changes. Because land use changes so rapidly around major urban centres, and because of the importance of such changes, there has been a concentration of research in land use monitoring. Prout (1980) used Landsat, aerial photographs and other remote sensing data to assess land use/cover mapping and monitoring in an urban-centred area in Nova Scotia. She has mentioned the problems of scale, resolution, class differentiation, and registration of images from different dates to monitor changes. From a print of a digitally enlarged Landsat scene, maps of urban, woodland, sand, rock, water and transportation classes were produced. Prout concluded that detection of change from one data source to another was possible, as well as from Landsat alone.

Rubec (1978) and Rubec and Thie(1978) analyzed Landsat data from 1972 and 1976 on CCRS's image analysis system (CIAS) to assess land use change in southwestern Manitoba, an area more analogous to southwestern Alberta than Nova Scotia. Supervised classification and a "post-classification change detection" technique were valuable for mapping change in woodland, agricultural land, and water, but not for urban and rangeland changes. Problems on the CIAS included scene registration and signature changes between dates and within scenes. Jackson et al. (1980), in a Landsat study of developed areas in England and Wales, encountered classification errors due to geometric data problems, inadequate spatial or spectral resolution, inadequate ground truth training, and lack of sophistication in the classification software. They attempted to improve accuracies by only including units greater than 2.5 ha, and through multitemporal analysis.

Schubert (1978), evaluating Landsat data for land use mapping and change detection in two study areas near Peace River, Alberta, used three computer and two visual techniques. Visual analysis of simulated color infrared (CIR) Landsat data on the CIAS monitor provided the best interpretation of land use, since it included colour, texture, and contextual information. Advantages of this approach include perfect registration of all bands and standardization of colours from scene to scene on the monitor (neither of which are found with the Landsat photographic enlargements produced by CCRS); one disadvantage was the lack of a permanent record from this interactive display. Feature boundaries separated by computer classification could be located only to the nearest of two pixels (or within $118 \mathrm{~m}$ ) in the scanning dimension, and to the nearest pixel (within $79 \mathrm{~m}$ ) in the satellite progression dimension, an important conclusion for the detection of small-scale changes.

In a land use study in Ohio, Gordon (1980) concluded that while open space and agricultural land could be mapped with accuracy, very large errors occurred in the urban categories due to registration errors, and to classification techniques. With relative success, Ohlen (1980) has used ratioing of multidate Landsat digital data to monitor changes in coal surface mining.

Other relevant studies consider the mapping and monitoring of vegetation with landsat data. Wickware (1978), mapping wetlands in northern Alberta, used visual interpretation of textural colour patterns of the automated classification results to produce generalized vegetation/hydrologic zones for monitoring environmental change. This combination of digital and visual interpretation techniques has been used by others (Prout 1980; Schubert 1978; Cihlar et al. 1978; Thompson 1981).

Eidenshink and Schmer (1978) found that digital analysis of Landsat computer compatible tape (CCT) data was the most effective and economic method inventory of aspen and other forest cover types in the Black Hills of South Dakota. With a 4 ha cell size, this provided baseline data for monitoring effects of aspen management, encroachment of pine on unmanaged areas of aspen, and encroachment of forest into the grasslands.

Jaques (1977) mapped changes in rangeland condition, based on radiometric differences between 1972 and 1975 (to accuracies of tenths of hectares) with Landsat digital data on the CIAS. He did not note the problems of resolution, spectral variability, geometry, and registration mentioned by most other researchers when comparing two or more sets of Landsat data.

In a publication summarizing the use of Landsat for monitoring changes in Canada (Thompson 1982), the methodological discussions in Ryerson et al. (1982) emphasize the use of generally simple analysis procedures and Digital Image Correction System (DICS) Landsat data for monitoring land use and agricultural changes.

In summary, remote sensing is a useful tool for monitoring vegetation changes in a variety of environments. Aerial photographs have been used most successfully in mapping localized natural and man-induced vegetative changes. The use of Landsat data is a less well-established technique. While Landsat data can be utilized for mapping land use and vegetation and for monitoring changes in these parameters, limitations related to resolution, spectral variability, geometry and registration still exist. The most successful analysis technique for Landsat data appears to be a combination of digital processing and visual interpretation, rather than a completely automated approach. Results in terms of spatial resolution vary 
widely: Jaques (1977) reported his results in tenths of hectares, Schubert (1978) about one hectare, Jackson et al. (1980) units of 2.5 ha or more, and Eidenshink and Schmer (1978) 4 ha.

Most reports mentioned the problem of spectral variability between dates and within scenes which leads to inaccuracies with automated computer analysis. Geometric distortion on the CIAS display image is a result of redundance in sampling of the Landsat data in the scanner direction (Schubert 1978); this can be adjusted in a "cosmetic" fashion, i.e., the image is altered to appear geometrically accurate (e.g., Prout 1980; Thompson 1981). This is important when photographic products are obtained from the display for visual interpretation.

Registration of Landsat data for two or more dates is subject to inherent problems when used to evaluate small-scale changes. Even with very careful ground control point (GCP) selection, it must be expected that registration errors will be in the order of one pixel. However, the present development of DICS data tapes by the CCRS as a standard Landsat data product will solve the multidate registration problem for future studies.

Thus it appears that the use of aerial photographs presents few problems for monitoring vegetation changes. The use of Landsat data will be limited by the amount (area) of vegetation change which is to be measured over the selected time interval, the spectral differences between the vegetation classes to be monitored, and the method of analysis of the Landsat data. The most promising approach appears to be a combination of visual interpretation and digital processing. As such, it was this approach which was evaluated for the southwestern Alberta Study area.

\section{STUDY AREA}

The study area (Figure 1), located in the Rocky Mountain foothills in southwestern Alberta at the north end of the Porcupine Hills, was selected for several reasons:

1. Relatively rapid rate of brush encroachment $(0.75 \% / y e a r$, compared to $0.25 \%$ for parkland to the north and east (Johnson and Smoliak 1968; Bailey and Wroe 1974));

2. Previous research in area at Agriculture Canada Stavely Research Substation and vicinity (Johnston 1961, 1970; Johnston and Smoliak 1968; Johnston et al. 1971; Thompson 1978; Brown et al. 1983; Alberta ENR 1979); and

3. Rancher interest in brush encroachment (range managers indicated local rancher participation in brush control programs involving clearing and spraying privately and in conjunction with Alberta Energy and Natural Resources, Public Lands Division).

Three transects were selected to incorporate representative vegetation communities and cleared areas, areas of good photographic and Landsat coverage, areas for which Dominion survey data were available, and areas reasonably accessible by road for the field work.

The area is located mainly within the Alberta parkland; aspen, and rough fescue and other grasses dominate the drier sites, while willow is found on the moister sites (North 1976). In the lower montane communities at higher elevations, Douglas fir (Pseudotsuga mensiesii) and limber pine (Pinus flexilis) are found; lodgepole pine (Pinus contorta var. latifolia) and white spruce (Picea glauca) grow at the higher elevations within the southern two transects. Much of the deciduous tree cover is recent (Johnston and Smoliak 1968), with woody communities increasing in density and area after establishment. On the moister sites, particularly in the remaining grassland, there are a number of low shrubs (shrubby cinquefoil (Potentilla fruticosa) and prickly rose).

The study area is comprised of three transects (Figure 1) 16 to $28 \mathrm{~km}$ in length, and $3.2 \mathrm{~km}$ wide. They cover the varied land use and vegetative communities typical of this region where annual precipitation from west to east in this area may vary as much as $100 \mathrm{~mm}$ (Atlas of Alberta 1969).

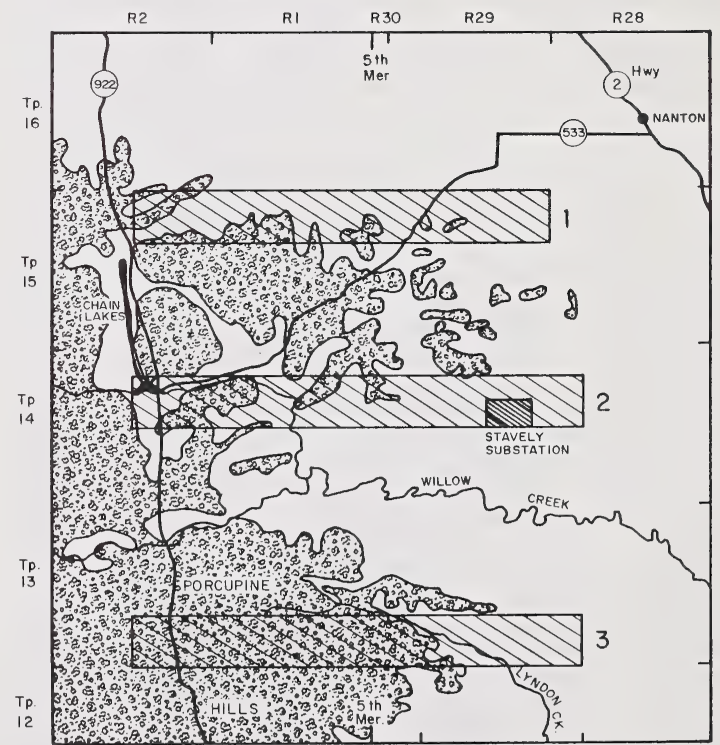

Fi: WOODED AREA

Figure 1. Location of the Brush Encroachment Study Area in Southwestern Alberta

The north transect (\#1) runs across cultivated hay land and native pastures. Shrubs (willow, rose, aspen, alder (Alnus spp.)) are found in the coulees and stream valleys, on the north-facing slopes, and in areas too rough for cultivation; there are few mature aspen. In the central transect (\#2), mature aspen (particularly in the 
west) and patches of willow, alder and low shrubs in the moister locations are found. The east end and Willow Creek Valley contain some cultivated pasture and hay land; west of Willow Creek, a relatively large area has recently been cleared of shrubs. The southern transect (\#3) includes lower montane communities of white spruce, lodgepole pine, and Douglas fir in the west (mainly north-facing and steeper slopes), usually mixed with aspen. The rest of the transect has mature aspen forest; east of Lyndon Creek willow and low shrubs are encroaching onto the grasslands from the moister drainages and coulees. There are few cultivated hay lands or pastures.

\section{MATERIALS}

Historic data used to establish previous locations of shrubs and trees included Dominion of Canada surveyor data from 1883 to 1907 (Table 1) (also used by Johnston and Smoliak (1968), and by Bailey and Wroe (1974) to evaluate shrub encroachment). The surveys were conducted along section lines; information on topography, drainage, cultural features, soils, elevations and distances were recorded in graphic and written form, as was the approximate location of "poplar", "scrub", "willow", "brush", "Balm of Gilead" (a poplar), "cottonwood", "dark pine", "spruce", "fir", "hay" and "grass" (Figure 2). Old aerial photographs (Table 1) included a 1949-1952 set of black and white $1: 40,000$ scale photographs for the two northern transects, and $a 1962$ set at $1: 31,680$ scale for all three transects.

Current data (Table 1) (i.e., from the past ten years) included $1: 7,500$ scale color infrared (CIR) transparencies covering a 14 $\mathrm{km}$ east-west line through the stavely Substation (part of the central transect). Because of their resolution, scale and colour format (compared to the smaller scale black and white aerial photographs from previous years), these were very useful for mapping shrubs. The major source of current remote sensing information was CCT's of Landsat data, obtained over as wide a time interval as possible (19 July 1973 to 27 July 1980).

After initial examination of map and aerial photography information, field surveys were conducted in September and November 1980 to gather information from the ranchers in the area concerning brush management, to view and photograph selected survey lines within the transects (in order to evaluate change in brush location since the early Dominion surveys), and to obtain ground data on recently cleared or brush-encroached areas for use in interpretation of the Landsat data.

Table 1. Remote Sensing and Ground Data used for Brush Encroachment Study.

\begin{tabular}{|c|c|c|c|}
\hline \multirow[t]{2}{*}{ DATA SETS } & \multicolumn{3}{|c|}{ TRANSECT } \\
\hline & 1 & 2 & 3 \\
\hline \multirow[t]{2}{*}{ HISTORIC DATA } & $\begin{array}{l}\text { Surveyor Data } \\
1883-1907\end{array}$ & $\begin{array}{l}\text { Surveyor Data } \\
1883-1907\end{array}$ & $\begin{array}{l}\text { Surveyor Data } \\
1883-1907\end{array}$ \\
\hline & $\begin{array}{l}\text { B/W air photos } \\
1952,1: 40,000 \\
\text { scale } \\
1962, \begin{array}{l}1: 31,680 \\
\text { scale }\end{array}\end{array}$ & $\begin{array}{l}\text { B/W air photos } \\
1952,1: 40,000 \\
\text { scale } \\
1962, \begin{array}{l}1: 31,680 \\
\text { scale }\end{array}\end{array}$ & $\begin{array}{l}\text { B/W air photos } \\
\begin{array}{l}\text { 1962, } 1: 31,680 \\
\text { scale }\end{array}\end{array}$ \\
\hline \multirow[t]{4}{*}{ CURRENT DATA } & -- & $\begin{array}{l}1977 \text { colour IR } \\
\text { photos, } 1: 7,500 \\
\text { scale (part of } \\
\text { transect) }\end{array}$ & -- \\
\hline & $\begin{array}{l}\text { Landsat CCT } \\
19 \text { July } 1973\end{array}$ & $\begin{array}{l}\text { Landsat CСT } \\
19 \text { July } 1973\end{array}$ & $\begin{array}{l}\text { Landsat CСТ } \\
19 \text { July } 1973\end{array}$ \\
\hline & $\begin{array}{l}\text { Landsat } \text { CCT } \\
27 \mathrm{July} \\
1980\end{array}$ & $\begin{array}{l}\text { Landsat CCT } \\
27 \mathrm{July} 1980\end{array}$ & $\begin{array}{l}\text { Landsat CCT } \\
27 \mathrm{July} 1980\end{array}$ \\
\hline & $\begin{array}{l}\text { Field Surveys } \\
\text { September } 1980 \\
\text { November } 1980\end{array}$ & $\begin{array}{l}\text { Field Surveys } \\
\text { September } 1980 \\
\text { November } 1980\end{array}$ & $\begin{array}{l}\text { Field Surveys } \\
\text { September } 1980 \\
\text { November } 1980\end{array}$ \\
\hline
\end{tabular}



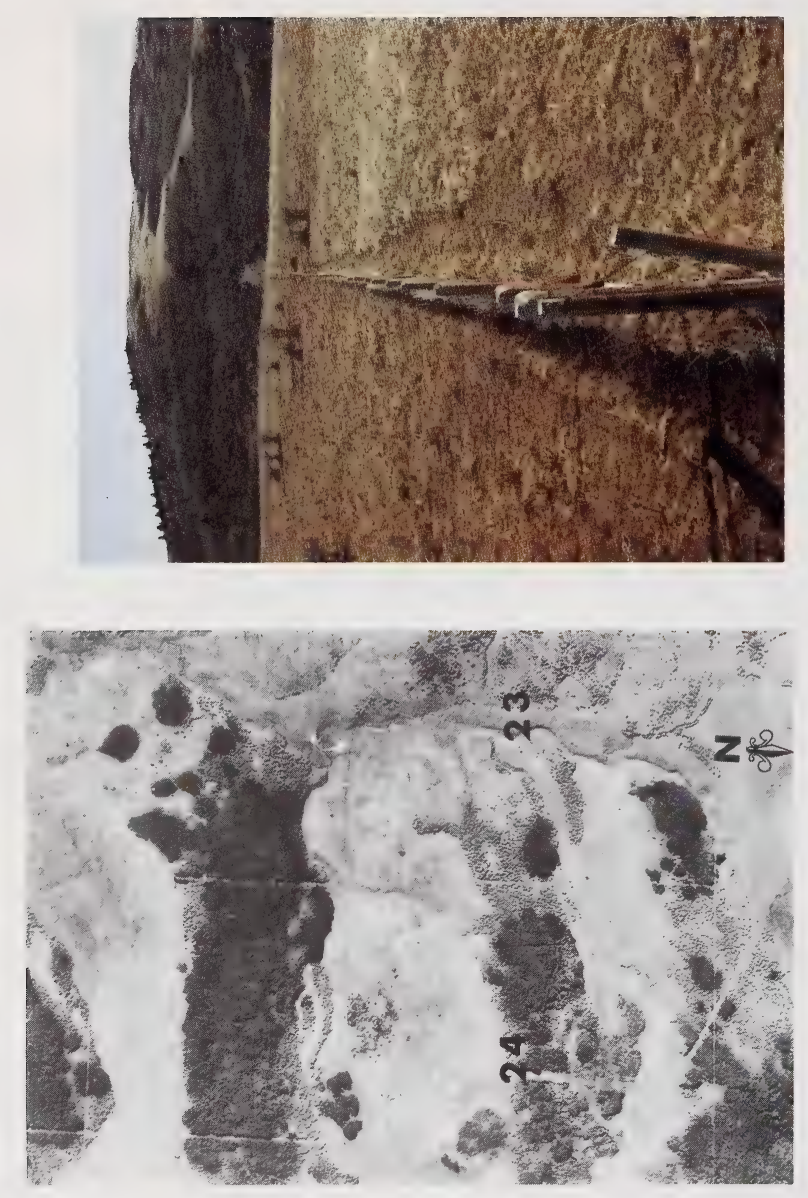

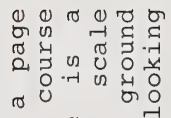

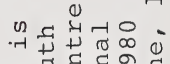

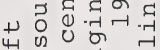

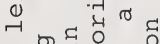

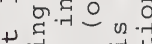

\% .

.. 造咨起莫

बैं ज्ञ

क न

0

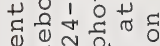

प्रे ले

दु द $\sim$ ल

us $\Rightarrow$ ro

-

वृ

0000

- $\begin{gathered}-1 \\ 0\end{gathered}$

践

in $.70-7$

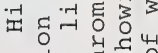

फ द्व द्वै ज्व

$\exists$

1

范

$y$

$$
\text { 일 }
$$$$
\text { क्ष }
$$

से

है।

है

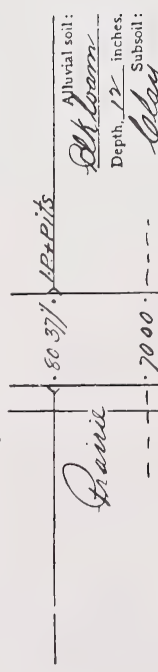

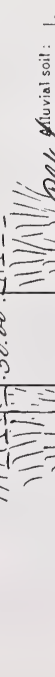

ح-

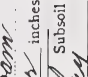

है

जै :

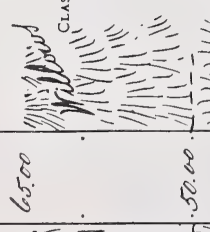
क्षे

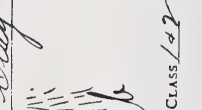

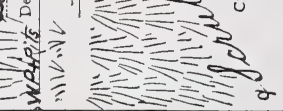

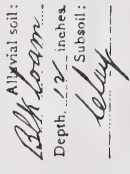

背三人

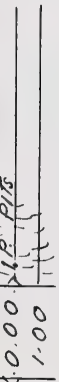

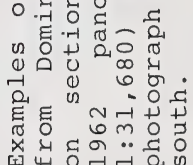

$\dot{\sim}$

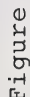

हैं 8 \& क 50 $\dot{Y}=$
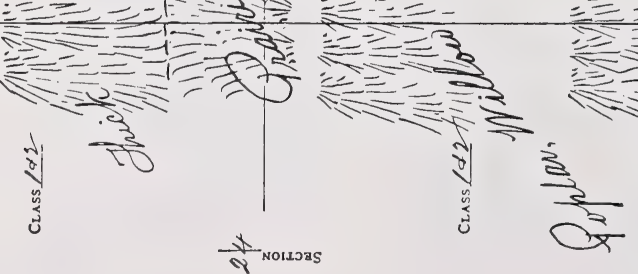

$\gamma$ NOIDIS 


\section{METHODS}

Methods for Analysis of Aerial Photograph and Surveyor Data

The brush data from the various time intervals were all transferred to a common scale for comparison $(1: 50,000$ scale NTS topographic base map). Although a smaller scale than ideal, it was the only published set of controlled geographic reference data available for the area.

Interpretation and transfer of data from the 1952 and 1962 air photos was accomplished using a Bausch and Lomb Stereo Zoom Transferscope (ZTS) ${ }^{l}$. It was possible also to superimpose an aerial photograph of one scale and date, onto another aerial photograph of a different scale and date, providing a view of the change in shrub height, density, and location from one date to another. Some photo interpretation was also carried out using a standard Wild-Heerbrugg ST-4 Mirror Stereoscope with three-power oculars.

While brush locations for 1952 and 1962 within the transects were mapped as base map overlays, the older surveyor data could not be areally mapped (as there was no information for the areas between the section lines). Instead, all of the pertinent brush information on the section lines was measured and transferred onto an overlay for the 1:50,000 scale map. Brush locations could thus be compared along section lines where the data from the aerial photographs intersected.

Two classes of brush cover were mapped: (1) brush/trees; and (2) open areas (grassland). This simple classification suited the objective of the mapping (i.e., to identify the boundary between brush and grassland at various points in time), and the nature and variety of the data from which the mapping was derived (e.g., particularly the simplistic surveyor data, and the small-scale Landsat data).

Although it is not known exactly how the Dominion Surveyors defined "brush" and "open areas" (and, in fact, whether it was consistent from one surveyor to another), their general approach was applied to the present mapping in order that the increases could be assessed in as consistent a manner as possible.

In order to evaluate the amount of encroachment which had occurred during the time intervals, three approaches were used.

1 With this instrument, a stereo pair may be viewed on a "stage", and the interpreted information transferred onto the 1:50,000 scale base map on the table below as the interpretation is carried out. This method could be used for most scales of remote sensing data because of adjustment in the magnification of the instrument.
In the first, for part of Transect 2, brush encroachment and brush clearance were mapped, and their locations from 1952 and 1962 overlaid on the 1977 photos. Problems related to relative location (with new ground control points (GCPs) and identification of shorter, less dense brush from the 1952 panchromatic photographs at $1: 40,000$ scale (difficult to distinguish from grass/forb communities) were encountered. Also, small areas of increase in the brush location from one date to another were difficult to physically outline on the photo overlays at this scale.

A second method provided sample data on the rate of brush increase/decrease from 1952-1977. The areas of brush within three selected sections on the photographs were measured using a dot grid $(100$ dots per square inch, Canadian Forestry Acreage grid A751). At the $1: 40,000$ scale, brush area could be measured to the nearest hectare, at $1: 31,680$ to $0.8 \mathrm{ha}$ and at $1: 7,500$ to $0.2 \mathrm{ha}$.

Finally, 30 section lines (about a 35\% sample) from each of the transects were selected for measurement. Along each line, the linear extent of open areas and of brush/tree cover was measured from the 1:50,000 scale overlays, summed for each data set (i.e., 19002, 1952, 1962), the percentage cover calculated for each transect, and the annual percentage change over the two time intervals (1900-1952 and 1952-1962) calculated. This same procedure was continued with the Landsat mapping, so that two additional sets of information were added (1973 and 1980).

\section{Field Data Collection and Analysis}

The field surveys were carried out to obtain verbal information from ranchers in the area, as well as to observe the current location of brush within the transect areas. Emphasis was placed on comparison of the early survey records with current brush status by visiting the same section lines. Many were difficult to locate, as they were not marked by fences, roads, or vegetation clearance, and were not readily accessible by road.

The field surveys also provided ground data for the analysis of the 1980 Landsat data. The location and date of any recent brush clearing, spraying, or planting within the transects, or the use of other management techniques related to brush were ascertained by observation and interviews with ranchers.

\section{Methods of Landsat Analysis}

Landsat CCT's covering the three transects from 1973 and from 1980 were analyzed on the CIAS (Goodenough 1976, 1979). Using this system, digital MSS data may be classified

2 The year 1900 was selected as representative of the average time of survey for which surveyor data had been obtained within the three transects. 
in a supervised ${ }^{3}$ or unsupervised manner, using any or all of the four spectral bands. Enhancement techniques (in which pixel intensities are altered rather than grouped) are also used. In contrast-stretching, the most successful technique applied in this study, pixel intensities within specified limits are stretched linearly between the 0 and 255 intensity range, and intensities outside the limits are set to 0 or 255.

Temporal overlays using the 1973 and 1980 data (for the central transect) involved the time-consuming process of registration of the raw data sets ${ }^{4}$ through selection of GCP's and then overlaying the raw data. The results were good, with the largest error within one pixel. The 1973 and 1980 Band 5 data, and the 1973 and 1980 Band 7 data were then overlaid to demonstrate changes, particularly in cleared areas. Ratios of the data, principal components enhancement, filtering, and several other techniques were applied to the data but did not produce reasonable results.

Two output techniques were used for the CIAS analyses: (1) $35 \mathrm{~mm}$ colour photographs of the colour television monitor (CRT) on which the data were represented during each analysis; and (2) grey-level maps of single bands, or supervised or unsupervised themes from the classification techniques on a versatec plotter (usually at a scale of $1: 50,000$, corresponding to the topographic

For supervised classification, the analyst selects predetermined features to be used in the training of the computer, which in turn defines the spectral signature files to be employed for the classification of all other areas that have the same spectral characteristics. Unsupervised classification does not require previous detailed knowledge of the physical boundaries of the features of interest. The entire selected area is scanned for spectral groups or clusters, and each pixel (picture element) is then assigned to one of these clusters. The interpreter assigns meaningful designations to these clusters in terms of what is known about the parameters of interest in the area. The techniques used are well documented (Goldberg and Schlien 1977; Goodenough 1976, 1979; Goldberg et al. 1975).

It should be noted that since the completion of this project, a new Landsat product called DICS (Digital Image Correction system) tapes have become routinely available. These tapes are radiometrically and geometrically corrected, and registered to an area one-quarter the size of a $1: 250,000$ NTS map. Use of DICS tapes in a program such as this would eliminate the need for manual registration from tape to tape, and for geometric correction on the monitor, thus making the whole process much more efficient. maps on which the other air photo and surveyor data were plotted).

The image displayed on the CRT is distorted geometrically as a result of about $33 \%$ redundance in sampling of Landsat data in the scanner direction (Schubert 1978). Therefore, a cosmetic geometric correction was applied for display of the Landsat data on the CRT, in order that the photographs of the transects would have approximately correct dimensions for data transfer.

For the visual analysis, the most useful colour slides and/or negatives were reproduced as $20 \times 25 \mathrm{~cm}$ colour prints (about 1:150,000 scale). The brush information could then be transferred onto the base map for comparison with other Landsat, aerial photograph and surveyor data in the three transects. The Landsat interpretation covered areas of brush increase, areas of brush decrease (through clearing or other management programs), and other changes in vegetation. Measurements of brush and open area along the sample section lines were then made on the Landsat data overlays, as described for the historic data.

The results of the visual Landsat interpretation could not be evaluated quantitatively for accuracy. Rather, they were compared to the field data in selected areas and accuracy qualitatively determined.

\section{RESULTS}

Figure 2 provides an example of the use of historic and current data in assessing brush encroachment in the study area. The 1904 surveyor data (on a south course along the section line between 23/24-14-1-W5) describe "thick willows" (from 50 to 70 chains) with "prairie" on either side. Comparison with the 1962 photograph shows that the brush has not encroached measurably to the south, but has encroached about $15 \mathrm{~m}$ north, and that a large proportion of this patch is aspen rather than willow. Although aspen follows willow in the successional sequence, this is a larger area of aspen than would be expected to succeed over this time interval; possibly the surveyor did not identify the aspen as such at the time of survey.

The ground photograph. (Figure 2) (looking south along the same section line) shows the willow and aspen composition of the patch, white spruce on the northeast-facing slope to the east (left) of the fenceline, and evidence of brush encroachment in the scattered shrubs within the grassland on both sides of the fence.

Figure 3 (view in conjunction with overlay in back pocket of this publication) illustrates changes in vegetation in the intervals from 1907 to 1952, from 1952 to 1962, and from 1962 to 1977 (changes from 1907 to 1952 are shown only along the section line which was surveyed in 1907, as no data are available for the areas between the section lines).

From 1907 to 1952, relatively large brush 


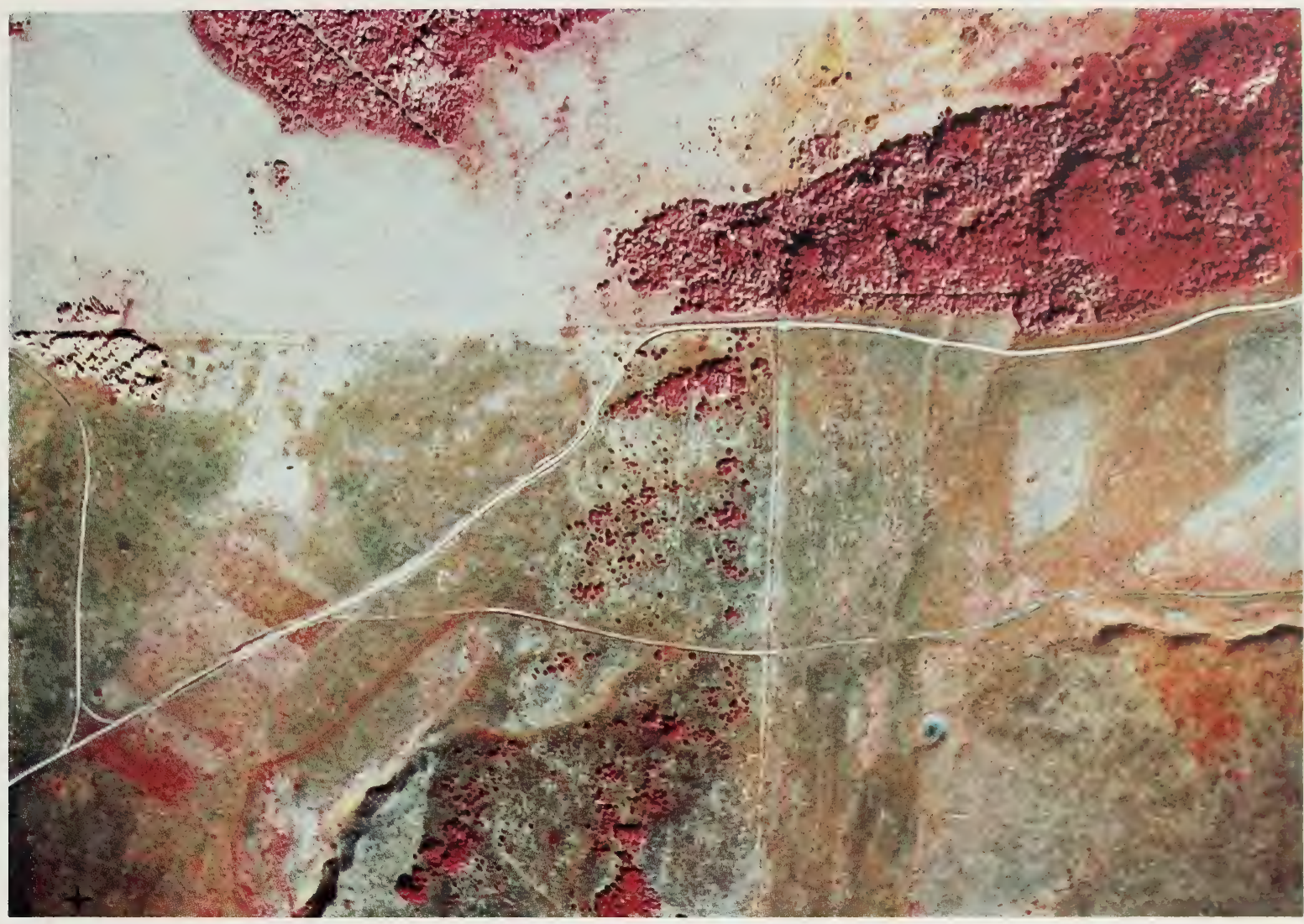

Figure 3. CIR Photo (A37530IR-101, 1:7,500) Obtained 13 September, 1977, of North Boundary of Stavely Research Substation (22-14-29-W4), with Overlay (back pocket of this publication) Illustrating Brush Encroachment since 1907.

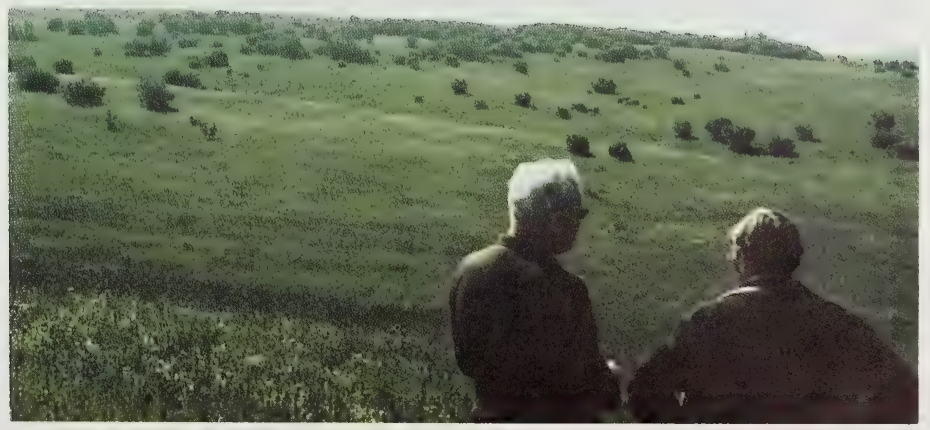

Figure 4.

View of Encroaching Willow in Abandoned Field, Noted on 1977 CIR Photo (looking east, 14 July, 1977, Stavely Research Substation. 
increases occurred along this portion of the section line. The patch of willow and aspen in the west end was not mapped by the surveyors, nor was much of the larger aspen/willow patch to the east. During this period, the fields to the south of the section line were cleared, cultivated and later abandoned (A. Johnston, Lethbridge Research Station, Personal Communication to M.D. Thompson, $14 \mathrm{July} 1977$ ); by 1952, a few shrubs were seen in the abandoned field, and by 1977 (Figure 4) many willow were present.

From 1952 to 1962, and from 1962-1977, brush encroachment occurred primarily in the abandoned field. Meanwhile, very little encroachment in the 1952 to 1977 period was seen north of the section line loutside the Substation on private land), probably due to a difference in grazing management.

Comparison of the 1980 field data with the mapping from the panchromatic aerial photographs showed that in general the larger shrubs and all mature trees were included. Where the shrubs were about the same height as the grasses and forbs, and where they were scattered throughout such grassland, rather than found in denser clumps, they could not be consistently identified. Thus the boundary between the shrubs and the grasses or open areas was hard to delimit.

Within the area of coverage of the 1977 photographs, three sections $\left(7.8 \mathrm{~km}^{2}\right)$ were mapped and measured, and brush increase or decrease calculated on an annual basis. For the three sections, brush encroachment was calculated to be $0.04 \%, 0.12 \%$ and $0.32 \%$ per year respectively (from east to west) over the 25-year period. This produced an average figure of $0.16 \%$ per year, a figure lower than the $0.75 \%$ per year derived by Johnston and Smoliak (1968) in the same area, but higher than the values of Bailey and Wroe (1974), as would be expected. Taking into account the variation in encroachment rates according to location, species, climate and management, this value is considered reasonable and representative.

Figure 5 shows brush and open areas in six sections within Transect 2 , as mapped from the 1962 aerial photographs, and from the 1980 Landsat data. The difference in mapping detail is easily noted. However, as shown in the third map in Figure 5, the areas of brush encroachment and brush clearance can still be identified over this 18-year time interval.

Figure 6 presents the contrast-stretched (enhanced) Landsat digital data from 1973 (top) and 1980 (centre), for Transect 2 (outlined). A multitemporal overlay of Band 5 (red band) data from 1973 and 1980 is also shown (bottom).

Using the contrast-stretched Landsat data for 1973 and 1980, tree cover was relatively easy to map. Both aspen and coniferous trees showed up distinctly on the contrast-stretched data, and slightly less distinctly on the raw digital data (the latter because of lower infrared signature contrasts with the shrubs and forbs). In steeper terrain, the darker-appearing slopes could be confused with coniferous or dense aspen cover; however, the use of topographic maps in the subsequent visual interpretation solved this problem ${ }^{5}$. In the most effective contrast-stretched format, the open (grassland) areas were blue-green, the denser stands of aspen and conifers dark red to purple, and the brush a lighter red. Colour differences due to processing of the colour negatives and enlargement to prints were taken into account.

In Transect 2 (Figure 6), examination of the 1973 Landsat contrast-stretched (enhanced) colour print showed that the major aspen and coniferous wooded areas showed up distinctly, as did those areas which were barren or had predominantly grassy cover. Although small ponds could be seen, the small creeks could not be distinguished by their water signature; instead, riparian vegetation (mainly willow) and characteristic meandering pattern were used for identification (one exception was Willow Creek, in which water could be seen).

The secondary roads in the area (e.g. Highway 533 from the Chain Lakes to Nanton) could be identified readily, but tracks and gravel roads generally could not. Hay fields often were difficult to distinguish from the background of grass/forb native range, particularly in the western end of the transect where their field boundaries were not distinct. In the eastern end, however, where the fields were more regular and located within a setting of drier native grassland they were identified more easily. Interpretation of brush was difficult, particularly in the western end of the transect where the native grassland was more infrared reflective, and similar to the brush communities in signature. In the drier east end, even very small patches of brush were distinguishable against the dry grasslands. For example, willow encroaching into the abandoned field in Transect 2 (Figure 3) was identified easily using Landsat, as it is seen against a background of relatively pure and dry fescue grassland.

The 1980 Landsat data (Figure 6) show approximately the same characteristics. The scene has a generally "lighter" background, however, and some features such as roads and bare soil do not stand out as well as they did in 1973.

The differences in the appearance of the enhanced Landsat in 1973 and 1980 led to overestimation of brush cover in 1973 (where generally high infrared reflectance from grasses, forbs and shrubs caused some forb and small shrub communities to be mapped as brush), and underestimation of brush cover

5 In earlier stages, when supervised classification of trees and brush was attempted, the shadows were a source of confusion and constituted one of the reasons why supervised classification was rejected as a viable method. 


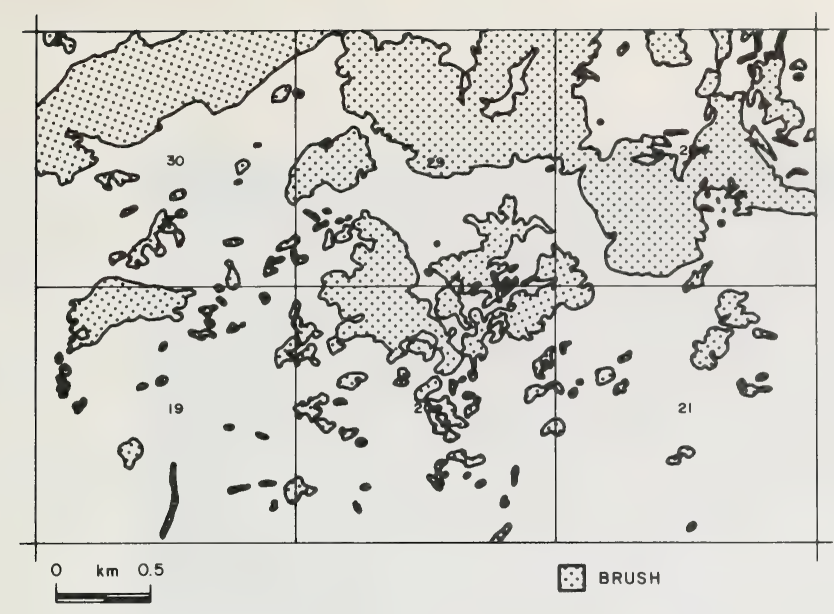

BRUSH AND OPEN AREAS 1962

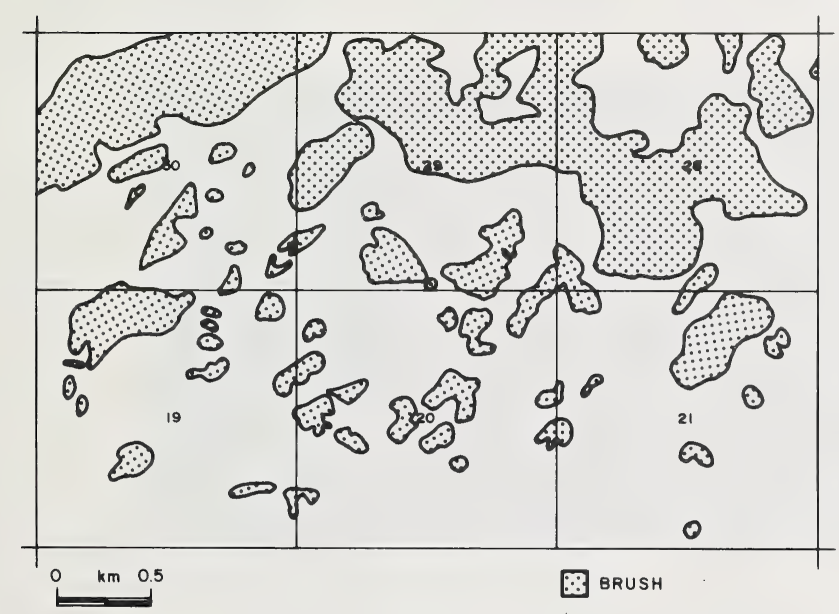

BRUSH AND OPEN AREAS 1980

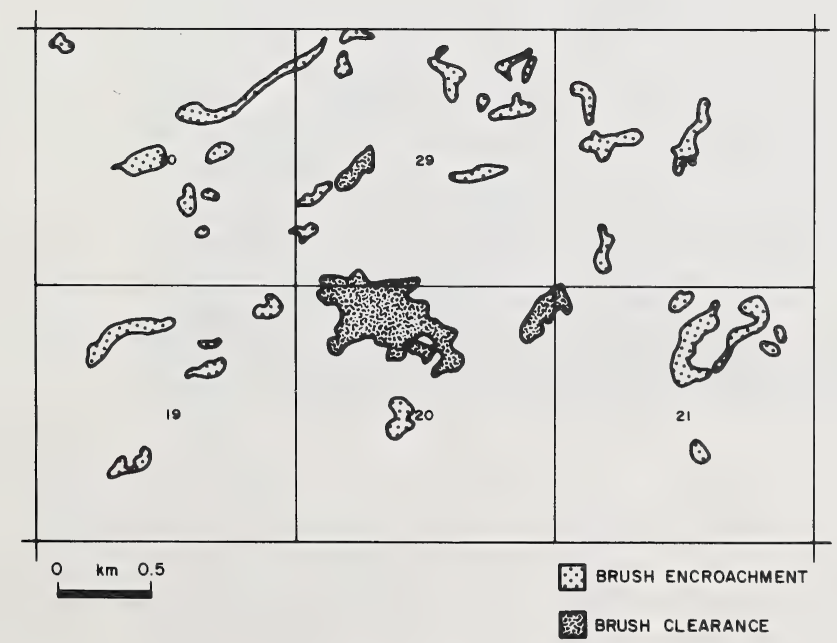

BRUSH ENCROACHMENT AND CLEARANCE 1962 - 1980

Figure 5. Brush and Open Areas Mapped from 1962 Photographs (top) and from 1980 Landsat Data (centre) for Six Sections in Transect 2. Bottom Map shows Brush Encroachment and Clearance Which Took Place During the 1962-1980 Interval. 

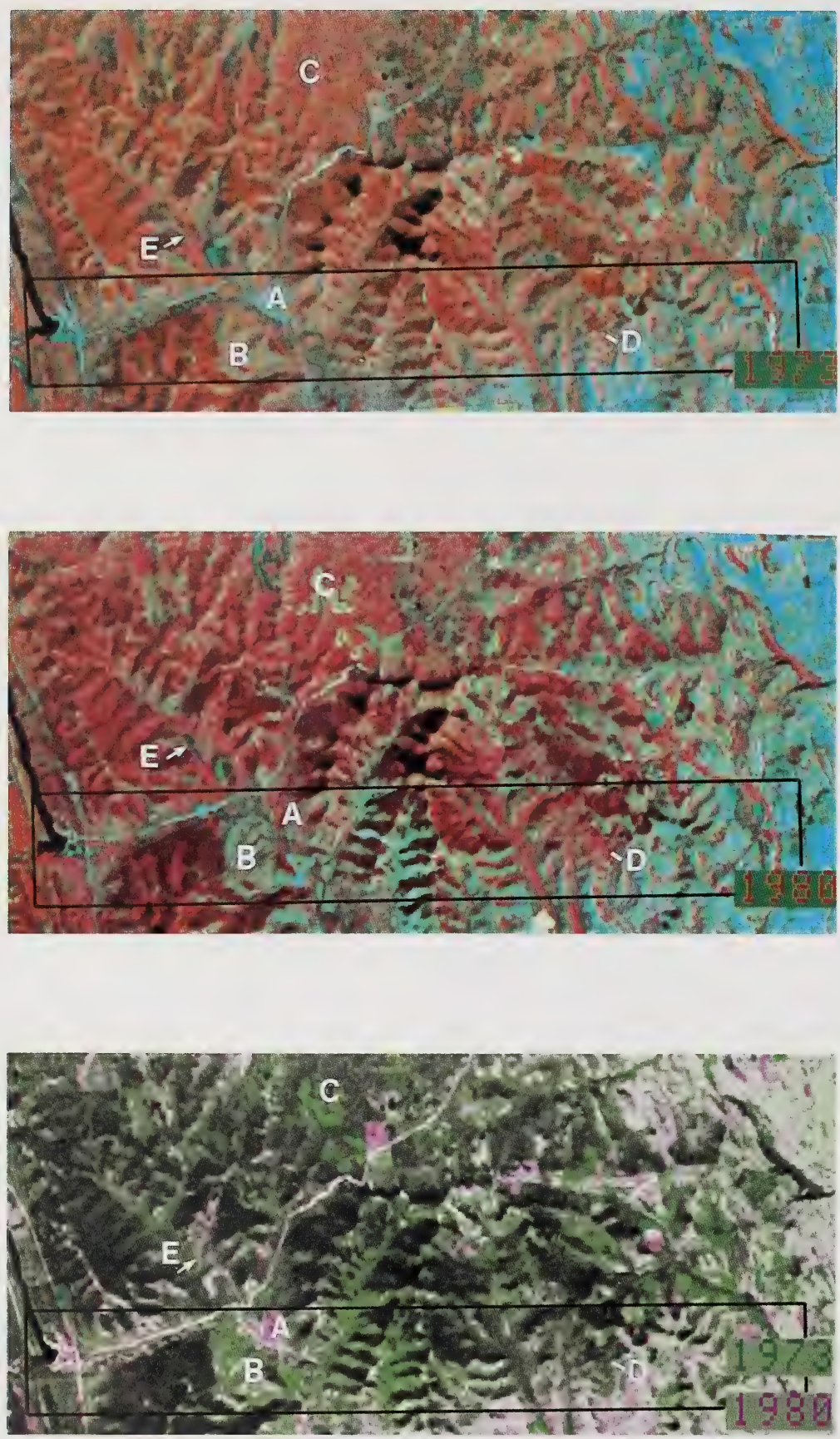

Figure 6. Colour Prints of 1973 (top) and 1980 (centre) Contrast-Stretched Landsat Digital Data, with Transect 2 Outlined on Each. Bottom Photograph shows a Multitemporal Overlay of Band 5 Data from 1973 and 1980. 
in 1980 (when lower infrared reflectance from ground cover caused some of the brush communities to be missed, or underestimated in areal extent). The ground surveys confirmed this for the 1980 data, but the overestimation in 1973 was inferred (since there was no ground survey at that time). The transects were then remapped more accurately, using the ground data as calibration.

Brush units as small as $80 \mathrm{~m}$ in diameter could be identified where a relatively dense stand was seen in level to undulating terrain in a dry grassland area. Where terrain was more sloping, the brush less dense, or the background vegetation had a similar signature, identifiable units were in the order of $150 \mathrm{~m}$ in diameter.

Accurate location of brush on the base maps was a major difficulty in mapping brush accurately using the colour Landsat photographs. While the cosmetic geometric correction was useful, there was still some distortion due to the characteristics of the non-planar colour monitor screen, the camera lens, etc. In addition, in a rangeland/foothills area such as this, there are few roads, cutlines, fields, creeks, and water bodies to use as GCP's. Thus, some error had to be accepted in the encroachment measurements.

Brush was successfully detected by visual examination of the 1973 and 1980 colour prints and of the temporal overlays (Figure 6 , bottom) of the digital data. The temporal overlay technique was particularly useful for rapidly identifying areas of change. The major changes noted were large-scale ones: recent tree and brush clearance; encroachment of grass and shrubs over areas cleared previously; and new roads and associated construction.

Comparison of the photographs in Figure 6 shows an area (A) cleared prior to 1973; by 1980 , this area has been obviously overgrown by grass and brush. It appears pink in the multitemporal photograph, showing that it has overgrown during the period, as have the other pink areas. On the same ranch, a large area of land (B) on the edge of the Crown land was cleared prior to 1973 and was not overgrown in 1980, probably due to continued brush management. Farther north a large area of land (C) has been cleared of brush and trees since 1973 as seen on the 1980 print. It is bright green on the multitemporal photograph, showing its change to "cleared" in 1980.

On Crown land west of the Stavely Research Substation, a smaller area of land (D) has been cleared between 1973 and 1980. The 1962 photographs showed this area of willow and aspen to have cutlines through the brush, the 1973 Landsat showed the brush to be still there and the 1977 photographs and 1980 Landsat showed the patch cleared and regrowing to forbs. Thus, it must have been cleared between 1973 and 1977 .

Along Highway 533 to Nanton in 30-14-1-W5, and along Highway 922 near the Chain Lakes
Reservoir in 34-14-2-W5, new areas have been cleared between 1973 and 1980. Finally, north of Transect 2 in the Big Jim Creek Valley on privately owned land (and not on the adjacent crown land), a new field (E) has been cleared just prior to 1980 .

As mentioned previously, these relatively large changes were detected easily and mapped either visually, or using a temporal overlay technique (Figure 6). However, evaluating natural brush encroachment between these two dates was more difficult because of its small scale. At an anticipated rate of 0.50 to $0.75 \%$ per year, encroachment would be on the order of $1 \mathrm{~m}$ over the seven-year period for the smallest brush unit identified at $80 \mathrm{~m}$ diameter, too small to be measured with Landsat at its current resolution of $80 \mathrm{~m}$. In order for the brush increase to be measurable with Landsat at $80 \mathrm{~m}$ or greater, a brush patch encroaching over the seven years would have to be approximately $4 \mathrm{~km}$ in diameter. However, since such encroachment can occur in this area, measurements were made from the 1:50,000 scale Landsat overlays as with the surveyor data and the aerial photographs along selected section lines.

All of the data were used to evaluate brush encroachment within the three selected transects over the 80 -year period of record. The results of the brush mapping for the three transects over the period 1900 to 1980 are summarized in Table 2 and Figure 7 .

From the transect measurements, the relative percentage of open areas and brush cover for each date of record, the time interval since the last date, the total percentage change (positive or negative) in brush cover over that time interval, and finally the annual percentage change in brush cover positive or negative) were calculated. Lastly, an average annual change over the entire 80-year period for each transect was given.

Throughout the period of record, Transect I has a higher percentage of open areas than Transect 2, which in turn has more than Transect 3, the most southerly and heavily wooded transect. This difference is more marked in 1900 (22\%) than in 1980 (14\%), showing that brush increase has "filled in" a greater amount of the more prevalent open areas in the northern transects.

These data show some anomalous values. For example, from 1962 to 1973 in Transect 1 no brush increase is shown (38\%), while the increase from 1973 to 1980 is very high (16\%, for annual percentage change of $+2.28 \%)$. The 1973 mapping from Landsat data may have underestimated the brush cover; interpolation between 1962 and 1980 (Figure 7) suggests that the percentage of brush in 1973 should have been about $45 \%$ ( $+7 \%$ ). Similarly, the value for brush cover in Transect 2 in 1952 appears to be slightly underestimated at $25 \%$. Interpolation of the curve in Figure 7 indicates that the figure should be about $32 \%$ ( $+7 \%)$. This underestimation of brush in 1952 probably resulted from the poor quality and small scale of the panchromatic aerial 
Table 2. Summary of Brush Cover Changes from 1900-1980 in Three Transects.

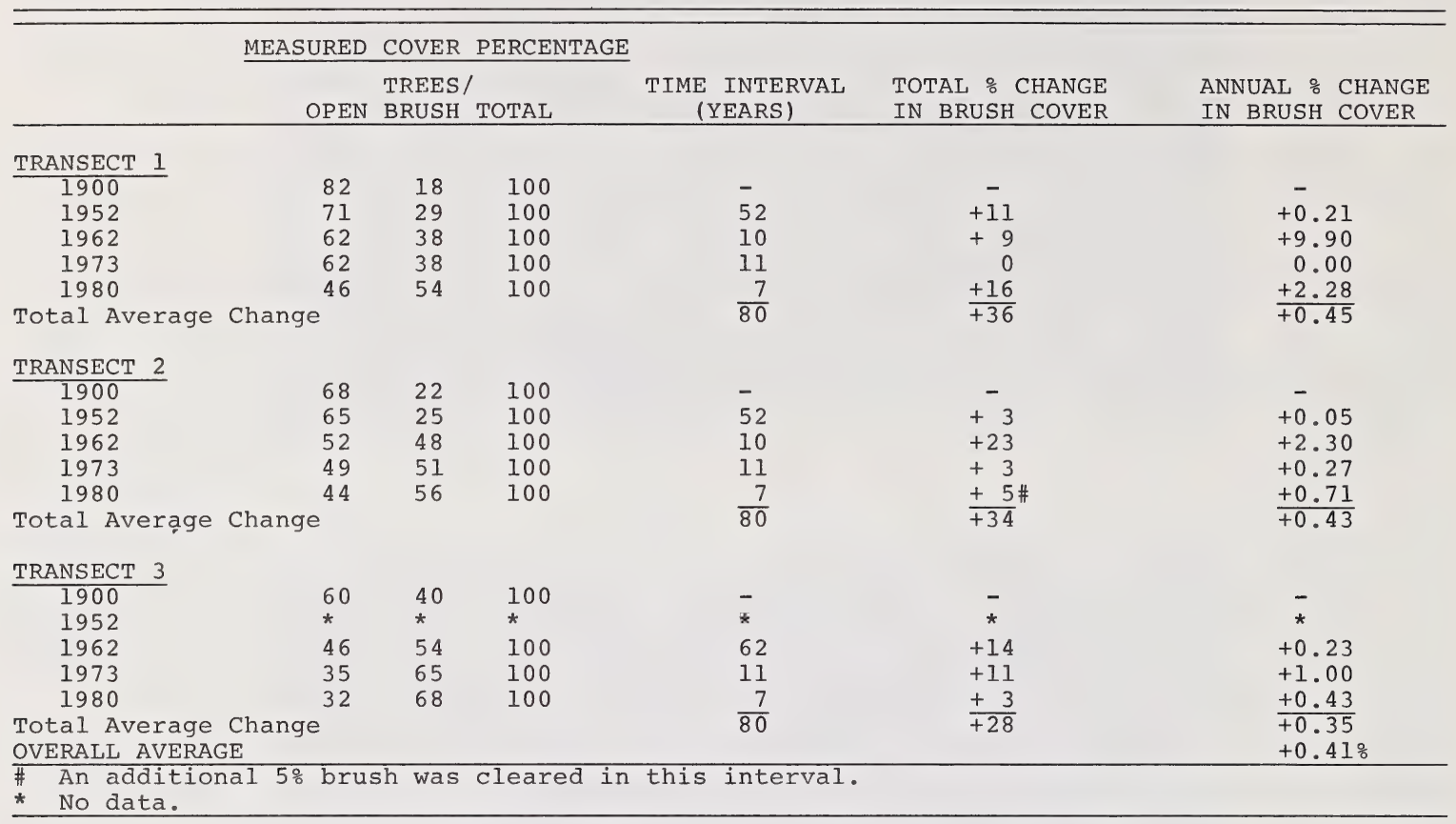

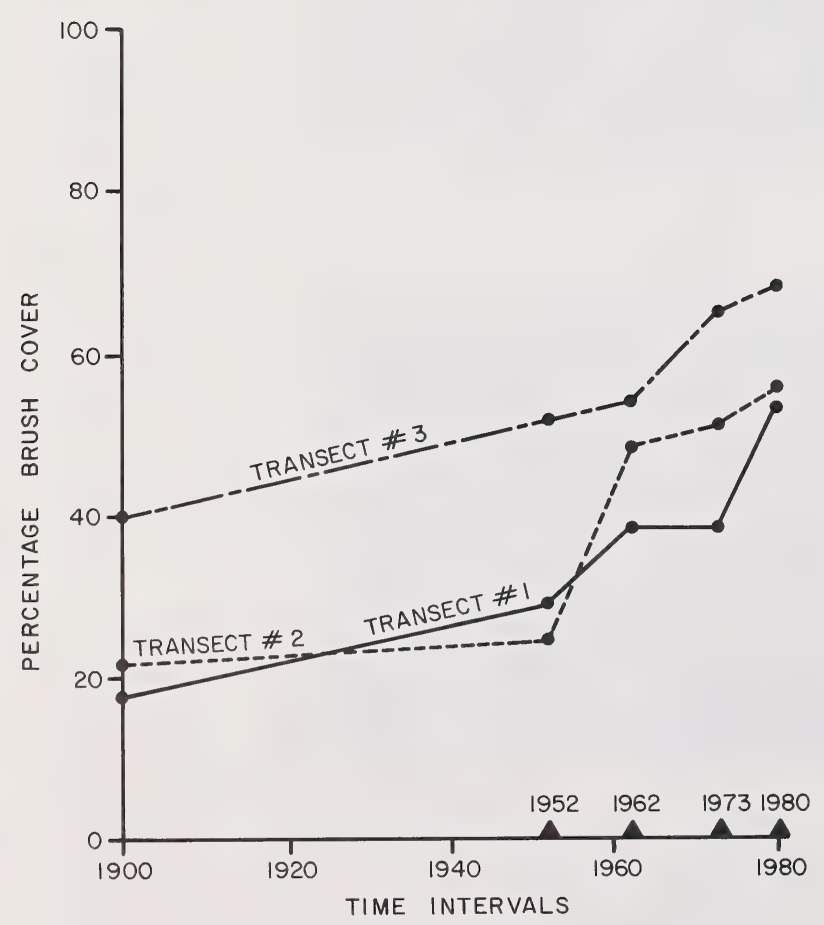

Figure 7. Brush Cover Percentage Changes in Three Transects During Four Intervals from 1900-1980, as Measured from Surveyor and Remote Sensing Data. photographs; it was much more difficult to identify brush on these photographs than on the large scale, better quality 1962 panchromatic photographs. It also could be argued that the percentage of brush cover in Transect 2 in 1962 was higher than would be expected, and would fit the curve better if reduced to about $40 \%$ However, these smaller scale anomalies may simply be due to brush management, and an increase or reduction in clearing programs within the measured areas.

An example of the effect of brush clearing on the results is seen in 1980 in Transect 2. Of the measured open areas, 5\% had been cleared since 1973, thus creating an "artificial" decrease in percentage of brush cover. Without this clearing, the brush percentage would be $61 \%$ rather than $56 \%$, thus accentuating the geometric increase seen in the latter years in these transects.

\section{DISCUSSION}

The mapping of brush encroachment was kept relatively simple with two classes (brush/trees and open areas) mapped. This suited the objective of the mapping (i.e., to identify the boundary between brush and grassland at various points in time), and the nature and variety of the data from which the mapping was derived (e.g., particularly the simplistic surveyor data, and the small-scale Landsat data).

The accuracy and detail of brush mapping from aerial photographs increased with scale and photo quality; the most accurate mapping was carried out with the $1: 7,500$ scale CIR transparencies. 
The successional sequence components of grass, willow, aspen and conifers could be identified, although the boundaries between these were difficult to place in many areas, a common mapping problem. Once the spectral signature for a boundary location was established for one data set, the same boundary had then to be identified on a different data set with a slightly different spectral signature. This applied not only to the different types, scales and dates of aerial photography, but also to the Landsat data. However, locational accuracy in the data transfer onto a common base map helped to solve this problem without the benefit of ground survey information from each of the dates mapped. As a result, the measurements of brush encroachment discussed later conform to expectations based on the literature.

Limited area measurements using aerial photographs in the east end of the central transect (Transect 2) showed that over the 25-year period from 1952 to 1977 , encroachment occurred on an average of $0.16 \%$ per year, increasing toward the west (from $0.04 \%$ to $0.32 \%$ ). Although the measured sections were not distributed widely east to west, and though the sample size was small, rates of encroachment were observed to increase with moister and higher environments, as noted in the literature.

Landsat digital data covering a seven-year interval were chosen for analysis on the CIAS. Of the several data classification and enhancement techniques evaluated for mapping brush, the most successful method was a combination of digital enhancement and visual interpretation. Supervised classification could be carried out reasonably well for tree and brush classes, but the brush boundaries were not considered accurate enough to allow confident comparison between dates.

Geometric adjustments of the data as seen on the CRT prior to photographing the data, and the use of a ZTS, helped to minimize the inherent geometric distortions. The contrast-stretched digital data for both dates were simply and inexpensively reproduced for interpretation as enlargements from $35 \mathrm{~mm}$ colour negatives. Contrast-stretching on the CIAS was carried out so that the results for the two dates would appear quite similar, reducing the tendency to overestimate or underestimate brush cover when trying to map consistently from two or more sets of data.

The Landsat interpretation showed that the signature of brush could be very similar to that of aspen, or of grassland with a high proportion of low shrubs and forbs. In the eastern, drier ends of the transects, the brush was identified more easily; in the western ends, pure grasslands were fewer, and the background had higher infrared reflectance, with a similar signature to that of brush.

Where brush was dense, and located in level to undulating terrain in a dry grassland area, units as small as $80 \mathrm{~m}$ could be identified; where the terrain was more rolling, the brush less dense and grassland greener, identifiable units were twice as large.

Large-scale brush changes were identified visually by comparing the two Landsat dates. Nearly all of the large changes involved brush clearance on one private ranch, both prior to 1973, and between 1973 and 1980. The boundaries between the privately owned and adjacent crown land in this area were obvious, as clearing generally was carried out only on private land.

Identification of natural brush encroachment was more difficult over the seven-year interval, since the Landsat resolution could barely record such changes. However, the measurement of open areas versus brush areas along selected lines did show changes over this period, as well as over the rest of the 80 -year period of record.

The measurements matched the trends identified in the literature. For all three transects, the encroachment of brush occurred consistently over the entire period with smaller increases in the earlier years, and larger increases in the later years (due to the geometric nature of such encroachment). It also could be seen that more brush encroachment by area occurred in the transect with the most open area at the beginning of the period, as would be expected. Except in very limited areas, the clearing programs within the study area have not kept pace with the natural brush encroachment; in fact, some of the areas cleared previously have reverted to brush over a relatively short time period where brush management has not remained active.

The results of the measurements of encroachment did show some anomalous values, most of which likely were due to underestimation or overestimation of brush cover using a combination of remote sensing media, times of year, scales, etc. Overall, however, the measurement results showed average values of encroachment of brush in all three transects within the limits of expectation, and in agreement with results from the literature.

\section{CONCLUSIONS}

Using mapping and measurement procedures, the analysis of historic and current data indicated that brush encroachment was in fact occurring at a relatively rapid rate within the study area, and that such could be evaluated using remote sensing data. The following conclusions were drawn from the study:

1. Aerial photography of a variety of scales $(1: 7,500$ to $1: 40,000)$ and types (panchromatic, CIR) can be used to map brush encroachment and clearance, with detail and accuracy dependent on the above factors;

2. Landsat digital data may be used to map brush, using a combination of digital enhancement and visual interpretation. 
Brush units as small as $80 \mathrm{~m}$ in diameter may be identified under optimal conditions. Terrain steepness, brush density and height, and prevalence of $a$ forb and lush grass background affect unit size and accuracy;

3. A variety of remote sensing tools and other data may be used for consistent mapping of brush encroachment. Choice of a common base map scale and transfer of interpreted information onto base map overlays, allows all data to be examined and measured in a common format:

4. Brush clearance also may be identified with Landsat and aerial photography according to amount and location. Because of its very distinctive spectral signature, it could be monitored on an annual basis using Landsat;

5. Natural encroachment of brush within the study area was occurring at a relatively rapid and apparently geometrically increasing rate, according to the remote sensing data. The rate of encroachment appears to vary with location and climate, and is on the order of $+0.41 \%$ per year, in agreement with those anticipated from the literature; and

6. Landsat data can be used for relatively inexpensive monitoring over large areas. Annual monitoring of brush clearance and other changes in land cover may be carried our effectively. Monitoring of natural brush encroachment with Landsat would be more effective, and conclusive if carried out over a longer time interval (e.g., 20 years), or with smaller-resolution Landsat imagery. 


\section{REFERENCES}

Alberta Energy and Natural Resources. 1979. Ecological land classification and evaluation-Livingstone-Porcupine. ENR Section, Edmonton. 89 pp. plus maps.

Atlas of Alberta. 1969. Government of Alberta and University of Alberta, Edmonton. $158 \mathrm{pp}$.

Avery, E.T. 1979. Interpretation of Aerial Photographs (3rd Ed.) M. Burgess Publishing Co., Minneapolis. 392 pp.

Bailey, A.W. 1972. Forage and woody sprout establishment on cleared, unbroken land in central Alberta. J. Range Manage. $25: 119-121$.

Bailey, A.W. and R.A. Wroe. 1974. Aspen invasion in a portion of the Alberta parklands. $\mathrm{J}$. Range Manage. $27(4): 263-266$.

Brothers, G. and E.B. Fish. 1978. Image enhancement for vegetative pattern change analysis. Photog. Eng. and Remote Sens. 44(5):607-616.

Brown, R.J., F.J. Ahern, K.B.P. Thomson, K. Staenz, J. Cihlar, C.M. Pearce and S.G. Klumph. 1983. Alberta rangeland assessment using remotely sensed data. Research Report 83-1, Canada Centre for Remote Sensing. Ottawa.

Cihlar, J., D.C. Thompson and G.H. Klassen. 1978. Mapping vegetation at $1: 1$ million from Landsat Imagery. Proc. 5 th Canadian Symposium on Remote Sensing, 28-31 August 1978, Victoria, B.C. $427-440$.

Clarke, A.B. 1967. A Photographic edge-isolation technique. Photog. Eng. and Remote Sens. 28(7):393-399.

Coupland, R.T. and J.S. Maini. 1959. Woodland invasion of western Canadian grasslands. Proc. 9th Inter. Bot. Cong. Montreal, P.Q.

Dalsted, K.J. 1978. Application of remote sensing to detect changes of habitat in the Black Hills (1961-1976). In Remote sensing applications to resource problems in South Dakota, Report No. I SDSU-RS1-78-14. NASA, Washington, D.C. $2-11$.

Eidenshink, J.C. and F.A. Schmer. 1978 The use of remote sensing technology to map aspen. In Remote sensing applications to resource problems in South Dakota, Report No. SDSU-RS1-78-14. NASA, Washington, D.C. $71-87$.

Friesen, H.A. et al. 1965. Brush control in western Canada. Canada Dep. Agr. Pub. No. 1240. Ottawa.
Goldberg, M. and S. Shlien. 1977. A

four-dimensional histogram approach to the clustering of Landsat Data. Proc. 1977 Machine Proc. of Remotely Sensed Data Symp. 250-259.

Goldberg, M., D. Goodenough and S. Shlien. 1975. Classification methods and error estimation for multi-spectral scanner data. Proc. 3rd Can. Symp, on Remote Sensing, September 1975, Edmonton. $125-144$

Goodenough, D. 1979. The image analysis system (CIAS) at the Canada Centre for Remote Sensing. Can. J. Remote Sens. $5(1): 3-17$.

Goodenough, D. 1976. Image 100 classification methods for ERTS scanner data. Can. J. Remote Sens. $2(1): 18-29$

Gordon, S.I. 1980. Utilizing Landsat imagery to monitor land use change: A case study in Ohio. Remote Sens. Envir. 9:189-196.

Jackson, M.J., P. Carter, T.F. Smith and W.G. Gardner. 1980. Urban land mapping from remotely sensed data. Photog. Eng. and Remote Sens. $46(8): 1041-1050$.

Jaques, D.R. 1977. The vegetation and effects of grazing on the eastern portion of the Suffield Military Reserve, Alberta. Range-Wildlife Study Committee, Edmonton. D41-D195.

Johnston, A. 1970. A history of the rangelands of western Canada. J. Range Manage. $23(1): 3-8$.

Johnston, A. 1961. Comparison of lightly grazed and ungrazed range in fescue grassland of southwestern Alberta. Can. J. Plant Sci. 41:615-622.

Johnston, A. and S. Smoliak. 1968 Reclaiming brushland in southwestern Alberta. $\mathrm{J}$. Range Manage. $21(6): 404-406$.

Maini, J.S. 1960. Invasion of grassland by Populus tremuloides in the Northern Great Plains. Ph.D. thesis, University of Saskatchewan, Regina. 231 pp.

Nielsen, U. 1972. Agfacontour film for the interpreter. Photog. Eng. and Remote Sens. $38(11): 1099-1105$.

North, M.E.A. 1976. A plant geography of Alberta. Univ. of Alberta Studies in Geography, Monograph 2. Dept. of Geography, Edmonton. 147 pp.

Ohlen, D.O. 1980. Detection of changes in a coal surface mining area by ratioing multidate Landsat digital data. Proc. 6 th Can. Symp. on Remote Sensing, 21-23 May 1980, Halifax, N.S. 581-582. 
Prout, N.A. 1980. Land use/cover mapping for Halifax county: Remote sensing alternatives. Proc. 6th Can. Symp. on Remote Sens. 21-23 May 1980, Halifax, N.S. $307-320$.

Reeves, R.G. (ed.). 1975. Manual of Remote Sensing. Vol. 1. American Society of Photogrammetry, Falls Church, Va. 867 pp.

Richter, D.M. 1969. Sequential urban change. Photog. Eng. and Remote Sens. $35(8): 764-770$.

Roller, N.E.G. 1978. Quantitative evaluation of deer habitat. Proc. Pecora IV Symposium: Application of Remote Sensing Data to Wildlife Management, Scientific and Technical Series \#3, 10-12 October 1978, Sioux Falls, South Dakota. 137-146.

Ross, D.S. 1976. Precision equidensity slicing with conventional photographic materials. Proc. 42nd Ann. Meeting, Am. Soc. Photogrammetry, Falls Church, Va. 239-249.

Rubec, C.D. 1976. Land use change detection using Landsat digital data. Unpub. report for Lands Directorate, Environment Canada, Ottawa. 52 pp.

Rubec, C.D. and J. Thie. 1978. Land use monitoring with Landsat digital data in southwestern Manitoba. Proc. 5th Can. Symp. on Remote Sensing, 28-31 August 1978, Victoria, B.C. 136-145.

Ryerson, R.A. et al. 1983. Landsat for monitoring agricultural intensification and urbanization in Canada. In Landsat for Monitoring the Changing Geography of Canada. M.D. Thompson (Ed.), CCRS, Ottawa. 4l-64.

Schubert, J.S. 1978, Computer processing of Landsat data for Canada Land Inventory land use mapping. CLI Report No. 13, Gregory Geoscience Ltd. Ottawa. 72 pp.

Simonett, D.S. 1974. Quantitative data extraction and analysis of remote sensor images. In Remote Sensing, J.E. Estes \& L.W. Senger (Eds.), Hamilton, Santa Barbara. 51-81.

Stelfox, H.A. 1980. Wildlife changes in southeastern Saskatchewan. Blue Jay $38(2): 69-79$.

Stelfox, H.A. 1979. Terrestrial wildlife habitat inventory of the Weyburn (62E)/Virden (62F) map area. Fisheries and Wildlife Branch, Saskatchewan Department of Tourism and Renewable Resources. Saskatoon, Saskatchewan. $213 \mathrm{pp}$.
Thompson, M.D. (Editor). 1982. Landsat for monitoring the changing geography of Canada. A special Report for COSPAR by The Geography Working Group, Canadian Advisory Committee on Remote Sensing. Canada Centre for Remote Sensing, EMR, ottawa, Ontario. $84 \mathrm{pp}$.

Thompson, M.D. 1981. Landsat analysis to identify and map saline dryland soils in southern Alberta - phase 11. Prepared for Agriculture Canada, Lethbridge Research Station, Lethbridge, Alberta. INTERA Report C80-009C, Calgary, Alberta. 105 pp.

Thompson, M.D. 1978. Remote sensing for estimation of rangeland productivity and condition at Stavely, Alberta. Prepared for Agriculture Canada, Lethbridge Research Station. INTERA Report C76-003C, Calgary, Alberta. 71 pp.

Wickware, G.M. 1978. Wetland mapping and environmental monitoring using Landsat digital data. Proc. 5th Can. Symp. on Remote Sensing, 28-31 August 1978, Victoria, B.C. 150-157. 


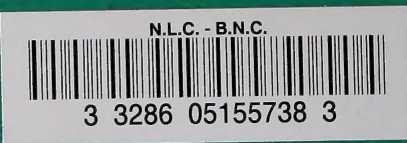

